\begin{tabular}{|c|c|c|}
\hline INNES & $\begin{array}{l}\text { Jurnal Fisika } 10 \text { (2) (2020) 27-34 } \\
\text { Jurnal Fisika } \\
\text { https://journal.unnes.ac.id/nju/index.php/jf/index }\end{array}$ & Jurnal Fisika \\
\hline & & \\
\hline
\end{tabular}

\title{
Pengukuran Etilen Hasil Proses Peroksidasi Lipid pada Biocream yang Diinduksi Sinar Ultraviolet menggunakan Detektor Fotoakustik
}

\author{
Ign Edi Santosa ${ }^{1}$ dan A. N. I. Harmita ${ }^{2}$ \\ ${ }^{1}$ Program Studi Pendidikan Fisika, Universitas Sanata Dharma \\ ${ }^{2}$ Paingan Maguwohardjo, Depok Sleman, Yogyakarta
}

\begin{abstract}
Info Artikel ABSTRAK
Sejarah Artikel:

Diterima:

4 Agustus 2020

Disetujui:

23 Desember 2020

Dipublikasikan: 28 Desember 2020

Paparan sinar ultraviolet (UV) pada kulit dapat menimbulkan kerusakan sampai kematian sel kulit melalui berbagai mekanisme seperti merusak DNA secara langsung dan pembentukan radikal bebas. Radikal bebas yang diinduksi oleh sinar ultraviolet menimbulkan proses peroksidasi lipid pada sel kulit. Proses tersebut ditandai dengan pancaran gas etilen yang dapat diukur dengan menggunakan detektor fotoakustik berbasis laser $\mathrm{CO}_{2}$. Penelitian ini mengunakan biocream yang mengandung lipid. Biocream dioleskan pada permukaan kaca dan dimasukkan ke dalam cuvet. Gas etilen yang dihasilkan diukur menggunakan detektor fotoakustik berbasis laser $\mathrm{CO}_{2}$. Etilen teramati selama pemaparan UV. Biocream bermassa 0,01 $\mathrm{g}$ yang dipapar UV dengan intensitas $16 \mathrm{~mW} / \mathrm{m}^{2}$ selama 15 menit menghasilkan etilen sebanyak $0,81 \mathrm{nl}$. Hasil

Keywords: ethylene, lipid peroxidation, photoacoustic, UV. ekpserimen menunjukkan bahwa etilen yang dihasilkan tergantung pada intensitas sinar ultraviolet dan massa biocream yang terkena paparannya. Pengukuran pada biocream sebanyak 0,05 g yang dipapar UV dengan berbagai intensitas memperlihatkan adanya hubungan linear antara produksi etilen dengan intensitas UV yang digunakan. Pemaparan UV dengan intensitas $16 \mathrm{~mW} / \mathrm{m}^{2}$ pada berbagai massa biocream menghasilkan etilen yang berbanding lurus dengan massa biocream terpapar.
\end{abstract}

\begin{abstract}
Ultraviolet (UV) exposure can damage the exposed area of the skin, eventually leading to the death of skin cells, via several mechanisms such as direct DNA damage and generation of reactive free radicals. The free radicals that are induced by ultraviolet radiation cause lipid peroxidation processes in the skin cells. The process is characterized by ethylene gas emission which can be measured using a $\mathrm{CO}_{2}$ laser-based photoacoustic detector. This study uses a biocream that contain lipids. The biocream is smeared on the glass surface and put into a cuvette. Ethylene gas is measured using a CO2 laser-based photoacoustic detector. Ethylene is observed during UV exposure. The biocream (mass of $0.01 \mathrm{~g}$ ) exposed to $16 \mathrm{~mW} / \mathrm{m}^{2} \mathrm{UV}$ radiation for 15 minutes produces $0.81 \mathrm{nl}$ of ethylene. The experimental results show that the ethylene production depends on the intensity of ultraviolet radiation and the mass of the biocream. Measurements on the biocream (mass of $0.05 \mathrm{~g}$ ) exposed to various intensities of $U V$ show a linear relationship between the ethylene production and the UV intensity. There is also The UV exposure with an intensity of $16 \mathrm{~mW} / \mathrm{m}^{2}$ on various biocream masses produce ethylene which is proportional to the exposed biocream mass.
\end{abstract}

(C) 2020 Universitas Negeri Semarang

$\begin{array}{lr}\text { Alamat korespondensi: } & \text { p-ISSN 2088-1509 } \\ \text { Program Studi Pendidikan Fisika, Universitas Sanata Dharma } & \text { e-ISSN 2684-978X } \\ \text { E-mail: edi@usd.ac.id } & \end{array}$




\section{PENDAHULUAN}

Paparan sinar matahari pada kulit menyebabkan kulit terlihat kemerahan atau terbakar. Spektrum sinar matahari sangat lebar meliputi daerah ultraviolet (UV), tampak, dan inframerah (IR). Sinar ultraviolet dari matahari dapat menciptakan radikal bebas yang merusak DNA dan mematikan sel kulit. Perubahan yang signifikan akibat paparan sinar matahari meliputi penuaan, lesi, kerutan, dan kanker pada kulit (Holick, 2016; Iordanis, 2020). Penelitian tentang kerusakan kulit akibat paparan sinar matahari antara lain menyangkut senyawa atau bahan yang dapat dimanfaatkan untuk pelindung, proses kerusakan, dan pengukuran tingkat kerusakannya.

Salah satu proses yang terkait dengan kerusakan kulit adalah munculnya radikal bebas reactive oxygen species (ROS) akibat paparan sinar ultraviolet. ROS dapat menyerang lipid bagian sel-sel dengan menimbulkan proses peroksidasi lipid (Harnita dkk, 2013; Lee dkk, 2013; Guzmán dkk, 2018). Hasil penelitian Lee dkk menunjukkan bahwa peroksidasi lipid meningkat $131 \%$ pada tikus yang terkena paparan sinar UV. Proses peroksidasi lipid menghasilkan berbagai macam produk akhir seperti gas etilen (Cristescu dkk, 2014; Paardekooper dkk, 2017). Karena itu etilen dapat dijadikan indikator proses tersebut.

Berbagai metoda telah digunakan untuk mendeteksi etilen, seperti kromatografi gas, electrochemical sensing dan deteksi secara optis. Masing masing metoda memiliki kelebihan dan kekurangan (Cristescu dkk, 2013). Deteksi secara optis menggunakan dasar proses serapan cahaya oleh molekul. Kelebihan deteksi secara optis seperti pada detektor fotoakustik adalah sensitivitasnya yang sangat tinggi, selektivitasnya bagus sekali, waktu tanggapnya sangat cepat dan dapat dioperasikan secara real-time. Detektor semacam ini dapat menggunakan berbagai jenis laser sebagai sumber cahayanya dan mampu mendeteksi berbagai jenis molekul. Detektor fotoakustik sensitif untuk pengukuran etilen (Patimisco, 2014; Wang dkk. 2017; Giglio dkk, 2019; Palzer, 2020). Deteksi etilen dengan detektor fotoakustik sangat bervariasi seperti pada bidang kesehatan, biologi, dan pertanian. Pengukuran etilen pada penderita ginjal kronis menunjukkan konsentrasi yang lebih tinggi dibandingkan pada orang yang sehat (Mitrayana dkk, 2020). Etilen juga diukur pada penderita schizophrenia (Popa dkk, 2015), pernafasan mulut dan hidung (Popa dkk, 2018). Pengukuran etilen dari buah apel juga memanfaatkan detektor fotoakustik (Nguyen Ba dkk, 2015; Wang dkk, 2016). Pengukuran semacam ini digunakan untuk uji kualitas buah pada tempat penyimpanan buah apel (Bratu dkk, 2020). Detektor ini juga telah digunakan untuk mengamati efek paparan sinar ultraviolet pada kulit manusia (Timmerman dkk, 1999; Harren dkk, 1999; Cristescu dkk, 2000).

Etilen teramati pada kulit manusia yang terpapar sinar ultraviolet. Proses emisi etilen bersamaan dengan paparan sinar ultraviolet. Konsentrasi etilennya berkurang ketika sinar ultraviolet dihalangi dengan penyerap UV (Harren dkk, 1999; Cristescu dkk, 2000). Hasil tersebut masih terbatas pada deteksi efek pemaparan sinar ultraviolet pada kulit. Respon kulit terhadap paparan sinar ultraviolet sangat tergantung pada orangnya. Berbeda dengan penelitian tersebut, pada penelitian ini pemaparan sinar ultraviolet dilakukan pada biocream yang mengandung lipid. Hal ini ditujukan untuk mendalami secara langsung proses peroksidasi lipid yang diinduksi oleh sinar ultraviolet. Pengukuran ini untuk menunjukkan ketergantungan produksi etilen terhadap jumlah lipid dan intensitas sinar ultraviolet yang memapar. 


\section{METODE}

Pada eksperimen ini detektor fotoakustik berbasis laser $\mathrm{CO}_{2}$ digunakan untuk mengukur etilen dari biocream (Merck, Germany) yang disinari dengan sinar ultraviolet. Biocream ini adalah ambiphilic dermatological cream yang mengandung lipid. Rangkaian peralatannya disusun seperti pada Gambar 1.

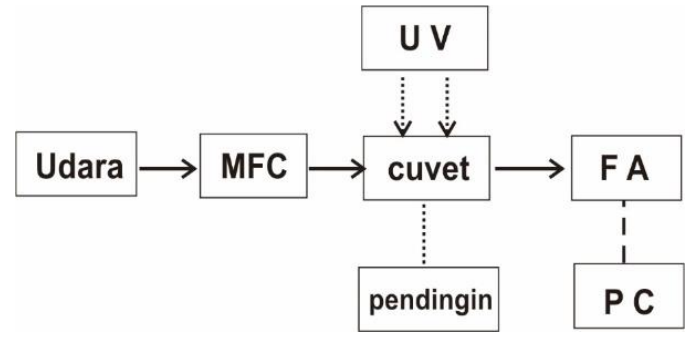

Gambar 1. Susunan peralatan yang digunakan dalam eksperimen.

Udara dialirkan melalui Mass Flow Controller (MFC) menuju cuvet berisi biocream yang disinari dengan sinar ultraviolet. Cuvet dirancang secara khusus dengan penutup gelas yang dapat ditembus sinar ultraviolet. Intensitas sinar ultraviolet diukur dengan menggunakan UVmeter. Pendingin digunakan untuk menjaga agar suhu cuvet tetap. Pendinginan dilakukan dengan mengalirkan air secara kontinyu dari water bath yang suhunya dijaga tetap.

Selanjutnya aliran udara tersebut akan membawa etilen yang diproduksi oleh biocream ketika disinari ultraviolet ke detektor fotoakustik (FA) berbasis laser $\mathrm{CO}_{2}$. Untuk mengurangi gangguan, sebelum masuk ke detektor fotoakustik, gas $\mathrm{CO}_{2}$ dan uap air yang terkandung pada aliran udaranya dihilangkan dengan menggunakan scrubber $\mathrm{KOH}$ dan $\mathrm{CaCl}_{2}$. Pada eksperimen ini laser $\mathrm{CO}_{2}$ dimodulasi dengan menggunakan chopper. Garis laser, frekuensi dan koefisien serapan etilen yang digunakan dalam eksperimen disajikan pada Tabel 1.

Tabel 1. Garis laser yang digunakan dalam eksperimen

\begin{tabular}{ccc}
\hline Garis laser & $\begin{array}{c}\text { Frekuensi } \\
\left(\mathrm{cm}^{-1}\right)\end{array}$ & $\begin{array}{c}\text { Koefisien serapan } \\
\text { etilen }\left(\mathrm{atm}^{-1} \mathrm{~cm}^{-1}\right)\end{array}$ \\
\hline 10P14 & 949,48 & 30,4 \\
\hline $10 \mathrm{P} 12$ & 951,19 & 4,3 \\
\hline
\end{tabular}

Daya laser diukur dengan sebuah powermeter, sedang sinyal akustiknya diukur dengan sebuah mikrofon dan diperkuat dengan lockin amplifier. Keluaran lockin amplifier dan powermeter diolah dengan menggunakan personal computer (PC) untuk mendapatkan nilai sinyal ternormalisir.

Langkah kalibrasi dilakukan terlebih dahulu untuk mendapatkan nilai konstanta yang diperlukan dalam penentuan nilai absolut konsentrasi etilen. Pada saat kalibrasi, etilen dengan konsentrasi 1 ppm dialirkan ke sel fotoakustik. Konstanta kalibrasi dapat ditentukan dari nilai pengukuran keluaran lockin amplifier dan powermeter serta konsentrasi etilen yang dialirkan (1 ppm). Dengan nilai konstanta kalibrasi ini, konsentrasi etilen dapat dihitung dari sebarang sampel, dengan mengukur sinyal ternormalisirnya.

Detektor fotoakustik yang sudah terkalibrasi selanjutnya digunakan untuk mengukur etilen dari biocream yang disinari dengan sinar ultraviolet. Pada setiap eksperimen biocream dioleskan pada permukaan kaca berdiameter $4 \mathrm{~cm}$ secara merata yang selanjutnya dimasukkan ke dalam cuvet. Pada percobaan pertama, pengukuran konsentrasi etilen dilakukan pada biocream dengan berbagai massa (antara $10 \mathrm{mg}$ sampai dengan $42 \mathrm{mg}$ ). Intensitas sinar ultraviolet pada percobaan pertama ini dibuat tetap sebesar $16 \mathrm{~mW} / \mathrm{m}^{2}$. Sedang pada percobaan kedua, biocream bermassa $53 \mathrm{mg}$ dipapar sinar ultraviolet dengan berbagai nilai intensitas (antara $12 \mathrm{~mW} / \mathrm{cm}^{2}$ sampai dengan $23 \mathrm{~mW} / \mathrm{cm}^{2}$ ). 


\section{HASIL DAN PEMBAHASAN}

Detektor fotoakustik terdiri dari sumber cahaya seperti laser, sel fotoakustik tempat sampel berada, microfon dan powermeter untuk mengukur daya laser. Detektor ini mengukur langsung intensitas cahaya yang diserap oleh sampel. Jika laser ditala pada frekuensi transisi dari molekul yang berada di dalam sel fotoakustik, molekul tersebut akan tereksitasi ke aras energi yang lebih tinggi. Pelepasan energi eksitasi secara non-radiasi berlangsung ketika molekul saling bertumbukan. Molekul akan mentrasfer energi eksitasinya ke energi translasi molekul yang ditumbuknya. Kenaikan energi translasi menyebabkan kenaikan suhu dan tekanan. Bila berkas laser dimodulasi, tekanan di dalam sel fotoakustik akan berubah secara periodik. Perubahan tekanan ini dapat diukur dengan menggunakan mikrofon (Henderson dkk, 2018).

Keluaran dari mikrofon tergantung pada daya laser, koefisien serapan dan konsentrasi gas, dan konstanta sel fotoakustik. Nilai koefisien serapan beserta konstanta sel fotoakustik diperoleh melalui kalibrasi. Selanjutnya konsentrasi gas di dalam sel fotoakustik dapat ditentukan dari pengukuran keluaran mikrofon dan daya laser.

Gambar 2 menunjukkan etilen yang dihasilkan oleh biocream dengan massa 0,01 g ketika disinari dengan sinar ultraviolet dengan intensitas $16 \mathrm{~mW} / \mathrm{m}^{2}$. Etilen tidak dihasilkan pada awal pengukuran karena belum ada penyinaran. Kemudian sesaat setelah disinari, etilen langsung dihasilkan dengan produksi yang relatif konstan selama penyinaran. Selanjutnya setelah penyinaran dihentikan, produksi etilennya juga langsung turun sampai nilai awal sebelum adanya penyinaran. Saat mulai dan akhir terdeteksinya etilen tidak tepat bersamaan dengan saat penyinaran, pada Gambar 2 terlihat adanya penundaan. Hal ini terkait dengan proses aliran gas pembawa dari cuvet menuju detektor fotoakustik.

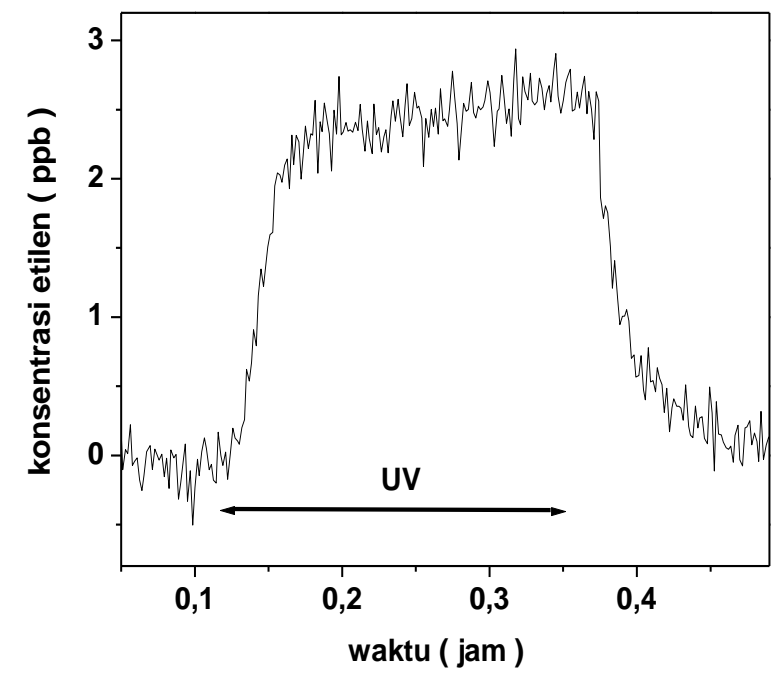

Gambar 2. Konsentrasi etilen (ppb) yang dihasilkan ketika biocream (0,01 g) disinari sinar ultraviolet. Garis berpanah pada gambar menunjukkan selang waktu pemaparan sinar ultraviolet.

Gambar 2 menunjukkan bahwa etilen dihasilkan hanya ketika biocream terpapar sinar ultraviolet. Hal ini sesuai dengan hasil pengamatan Cristescu et.al., paparan sinar ultraviolet pada kulit manusia akan menghasilkan etilen. Kulit yang dilindungi dengan lexan (bahan yang tidak transparan terhadap sinar ultraviolet), tidak memancarkan etilen (Cristescu dkk, 2000).

Pada eksperimen ini etilen dapat teramati karena adanya proses peroksidasi lipid yang terkandung dalam biocream. Proses ini dapat terjadi bila terdapat radikal bebas (Cristescu dkk, 2014; Paardekooper dkk, 2017). Sesuai dengan keterangan di depan, paparan sinar ultraviolet pada biocream menyebabkan pembentukan radikal bebas. Hal ini sesuai dengan hasil pengamatan Ramachandran dkk (2010) yang menunjukkan bahwa konsentrasi ROS pada fibroblasts kulit manusia yang terpapar sinar ultra violet lebih tinggi dibanding dengan kontrol. Pengukuran Caputo dkk. (2015) pada bahan lotion $\mathrm{TiO}_{2}$ yang dipapar dengan sinar UV memberikan sinyal pada Electron 
Paramagnetic Resonance (EPR), sebaliknya tidak ada sinyal EPR ketika dipapar dengan sinar tampak. Sinyal EPR ini menjadi penanda keberadaan radikal bebas.

Nilai produksi total etilen selama pemaparan sinar ultraviolet dapat dihitung dari Gambar 2. Total produksinya didapat dari nilai luas di bawah kurva dikalikan dengan laju aliran gas pembawa. Luas di bawah kurva pada Gambar 2 adalah 0,5524 ppb jam, dan laju aliran gas pembawa adalah 1,46 liter/jam. Kedua nilai tersebut memberikan produksi etilen sebanyak 0,81 nano liter.

Eksperimen juga dilakukan pada biocream dengan berbagai massa untuk mengetahui pengaruh jumlah lipid pada hasil proses peroksidasi lipid. Intensitas sinar ultraviolet pada eksperimen ini dibuat sama sebesar $16 \mathrm{~mW} / \mathrm{m}^{2}$ demikian pula selang waktu pemaparannya selama 15 menit. Nilai produksi etilen total yang dihasilkan disajikan pada Gambar 3.

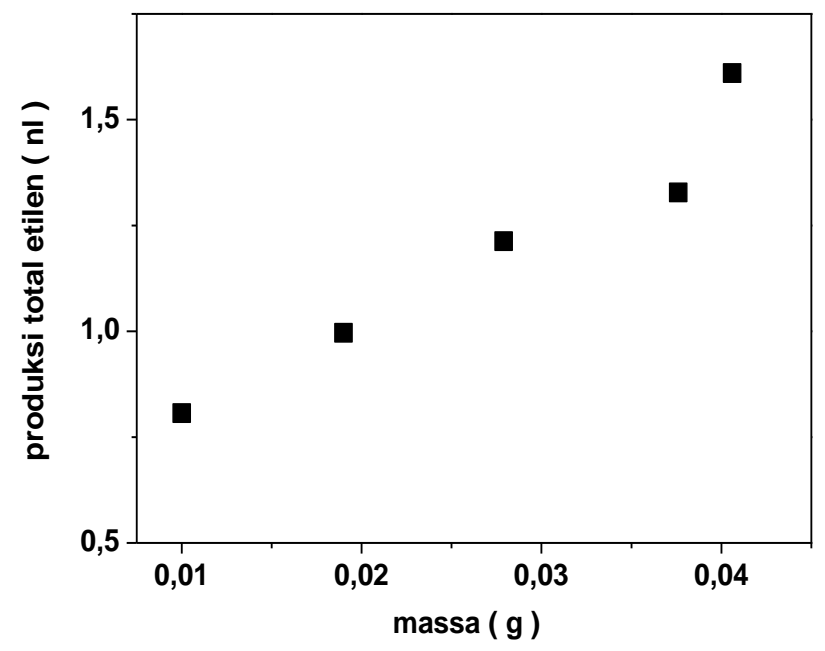

Gambar 3. Produksi total etilen (nl) yang dihasilkan oleh berbagai massa biocream, ketika disinari sinar ultraviolet dengan intesitas $16 \mathrm{~mW} / \mathrm{m}^{2}$ selama 15 menit.

Gambar 3 di atas menunjukkan pengaruh massa pada nilai etilen yang dihasilkan. Kadar lipid dalam biocream yang digunakan sudah tertentu. Kadar ini menyatakan massa lipid per satuan massa biocream. Jumlah lipid yang mengalami proses peroksidasi berbanding lurus dengan massa biocream yang digunakan. Karena itu kenaikan massa biocream akan menyebabkan kenaikan produksi etilen hasil dari proses peroksidasi lipid.

Etilen yang diproduksi merupakan hasil peroksidasi lipid yang terkandung dalam biocream. Proses ini diinduksi oleh sinar ultraviolet. Karena itu pengamatan juga telah dilakukan pada biocream yang sama massanya, dan disinari dengan berbagai intensitas sinar ultraviolet. Mengacu pada Gambar 2, konsentrasi etilen selama pemaparan UV terlihat relatif konstan. Karena itu nilai tersebut dapat digunakan sebagai ukuran pengaruh intensitas sinar ultraviolet. Nilai konsentrasi etilen (ppb), dari biocream bermassa $53 \mathrm{mg}$ yang disinari UV dengan berbagai intensitas ditampilkan pada Gambar 4. Gambar 4 menunjukkan bahwa kenaikan intensitas sinar ultraviolet disertai dengan kenaikan produksi etilen. Hal ini menunjukkan bahwa radikal bebas (reactive oxygen species) yang dihasilkan sebanding dengan intensitas sinar ultraviolet yang digunakan. Hasil ini sesuai dengan pengamatan pada kulit yang terpapar UV. Penggunaan antioksidan menurunkan TBAR yang merupakan indikator proses lipid peroksidasi. Penurunan lipid peroksidasi sesuai dengan penurunan radikal bebas (Balestrin dkk, 2016). 


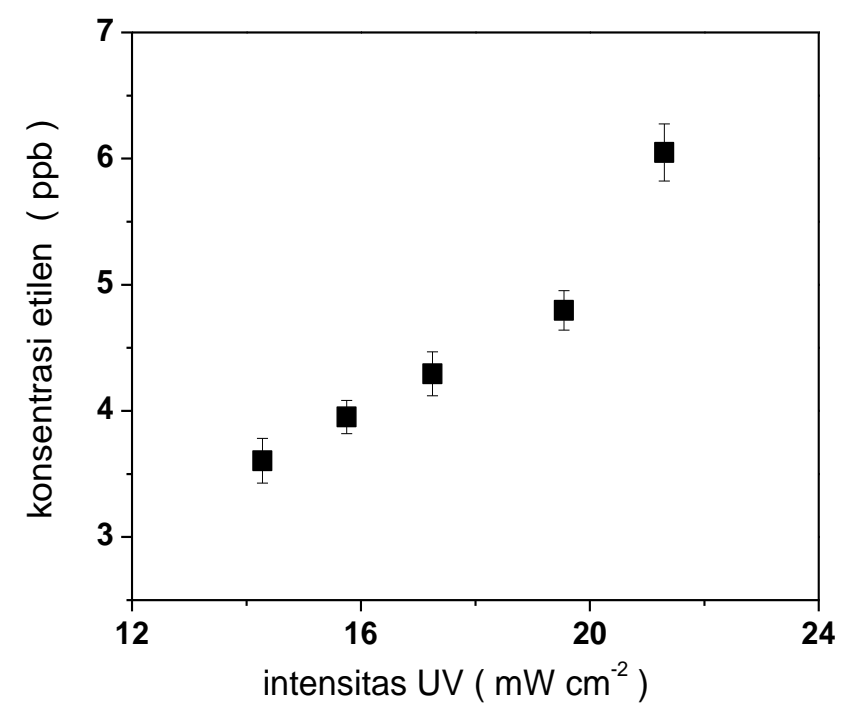

Gambar 4. Konsentrasi etilen (ppb) yang dihasilkan oleh biocream (53 mg), ketika disinari sinar ultraviolet dengan berbagai intensitas.

Kulit dapat dilindungi dengan sunfilter untuk menangkal efek merusak dari sinar ultraviolet. Kemampuan sunfilter telah diuji secara in-vivo pada kulit manusia (Timmerman dkk, 1999). Pada pengujian ini kulit orang disinari dengan sinar ultraviolet. Kemampuan sunfliter diukur melalui perbandingan pancaran etilen dari kulit yang dilindungi dengan sunfilter dengan pancaran etilen dari kulit tanpa pelindung. Kelemahan pengujian seperti ini terkait dengan sifat adaptasi kulit terhadap paparan sinar ultraviolet. Dengan demikian pengujian ini tidak dapat dilakukan secara bebas setiap saat.

Berbeda dengan pengujian in-vivo di depan, penelitian ini mengunakan detektor fotoakustik untuk mengukur produksi etilen dari biocream. Etilen tersebut dihasilkan dari proses peroksidasi lipid yang diinduksi oleh sinar ultraviolet. Karena itu selanjutnya metoda pengukuran etilen pada biocream ini, dapat diterapkan sebagai penanda kemampuan cream pelindung dalam menangkal efek merusak dari sinar ultraviolet. Cream yang dicampur dengan penyerap UV dan antioksidan, akan mengurangi keberadaan ROS dan selanjutnya mengurangi proses peroksidasi lipid (Harnita dkk, 2013). Hal ini dapat ditandai dengan penurunan produski etilen. Pengujian semacam ini tidak menggunakan kulit manusia secara langsung, sehingga dapat digunakan secara bebas.

\section{SIMPULAN}

Cream yang mengandung lipid ketika dipapar sinar ultraviolet menghasilkan etilen. Hasil ini menunjukkan secara langsung bahwa sinar ultraviolet dapat menginduksi proses peroksidasi lipid melalui pembentukan radikal bebas. Produksi etilen pada proses ini tergantung dengan jumlah lipid dan intensitas sinar ultraviolet yang digunakan.

\section{REFERENSI}

Balestrin, L.A., Bidone, J., Bortolin, R.C., Moresco, K., Moreira, J.C., \&Teixeira, H.F. (2016) Protective effect of a hydrogel containing Achyrocline satureioides extract-loaded nanoemulsion against UV-induced skin damage. Journal of Photochemistry \& Photobiology, B: Biology, 163, 269-276.

Bratu, A.M., Petrus, M., \& Popa, C. (2020). Monitoring of Post-Harvest Maturation Processes inside Stored Fruit Using Photoacoustic Gas Sensing Spectroscopy. Materials, 13, 2694.

Caputo, F., De Nicola, M., Sienkiewicz, A., Giovanetti, A., Bejarano, I., Licoccia, S., Traversa, E., \& Ghibelli, L. (2015). Cerium oxide nanoparticles, combining antioxidant and UV shielding properties, prevent UV-induced cell damage and mutagenesis. Nanoscale, 7(38),15643-56. 
Cristescu, S., Berkelmans, R., te Lintel Hekkert, S., Timmerman, B., Parker, D., \& Harren, F. (2000). Photoacoustic trace gas detection of ethene released by UV-induced lipid peroxidation in humans, Proc of SPIE, Vol 4162, 101-105.

Cristescu, S.M., Mandon, J., Arslanov, D., De Pessemier J., Hermans, C., \& Harren, F.J.M (2013). Current methods for detecting ethylene in plants. Annals of Botany, 111, 347-360.

Cristescu, S.M., Kiss, K., te Linterl Hekkert, S., Dalby, M., Harren, F.J.M., Risby, T.H., \& Marczin, N. (2014). Real-time monitoring of endogenous lipid peroxidation by exhaled ethylene in patients undergoing cardiac surgery. Am J Physiol Lung Cell Mol Physiol, 307, 509-515.

Giglio, M., Elefante, A., Patimisco, P., Sampaolo, A., Sgobba, F., Rossmadl, H., Mackowiak, V., Wu, H., Tittel, F.K., Dong, L., \& Spagnolo, V. (2019). Quartz-enhanced photoacoustic sensor for ethylene detection implementing optimized custom tuning fork-based spectrophone. Optics Express, 27(4), 4271-4280.

Guzmán, N.E.R., Mendía, L.E.S., Zúñiga, L.J.B., España, J.C.R., Infante, J.A.G., Mendoza, C.I.L., Gómez, C.I.G. (2018). Effect of Buddleja scordioides K. leaves infusion on lipid peroxidation in mice with ultraviolet light-induced oxidative stress. Medicinal Chemistry Research, 27, 23792385.

Harnita, A.N.I., Santosa, I.E., Martono, S., Sudarsono, Widyarini, S., \& Harren, F.J.M. (2013). Inhibition of lipid peroxidation induced by ultraviolet radiation by crude phlorotannis isolated from brown algae sargassum hystrix v. buxifolium c. agardh, Indo. J. Chem., 13 (1), $14-20$.

Harren, F.J.M., Berkelmans, R., Kuiper, K., te Lintel Hekkert, S., Scheepers, P., Dekhuijzen, R., Hollander, P., \& Parker, D.H. (1999). On-line laser photoacoustic detection of ethene in exhaled air as biomarker of ultraviolet radiation damage of the human skin. Appl Phys Lett, 74(12), 1761-1763.

Henderson, B., Khodabakhsh, A., Metsälä, M., Ventrillard, I., Schmidt, F.M., Romanini, D., Ritchie, G.A.D., te Lintel Hekkert, S., Briot, R, Risby, T., Marczin, N., Harren, F.J.M., Cristescu, S.M. (2018). Laser spectroscopy for breath analysis: towards clinical implementation. Applied Physics B 124:161.

Holick, M.F. (2016). Biological Effects of Sunlight, Ultraviolet Radiation, Visible Light, Infrared Radiation and Vitamin D for Health. Anticancer Research, 36: 1345-1356.

Iordanis, P. (2020). Comparative study on the effect of solar radiation on workers' skin at different altitudes. J Dermat Cosmetol, 4(1),14-18.

Lee, C.W., Ko H.H., Lin, C.C., Chai, C.Y., Chen, W.T., \& Yen, F.L. (2013). Artocarpin attenuates ultraviolet B-induced skin damage in hairless mice by antioxidant and anti-inflammatory effect. Food and Chemical Toxicology, 60, 123-129.

Mitrayana, Nikita, J.G., Wasono, M.A.J.,\& Satriawan, M. (2020). CO2 laser photoacoustic spectrometer for measuring ethylene, acetone, and ammonia in the breath of patients with renal disease. Sensing and Bio-Sensing Research, 30, 100387.

Nguyen Ba, T., Triki, M,. Desbrosses, G., \& Vicet, A. (2015). Quartz-enhanced photoacoustic spectroscopy sensor for ethylene detection with a $3.32 \mu \mathrm{m}$ distributed feedback laser diode. Review of Scientific Instruments, 86, 023111.

Paardekooper, L.M., van den Bogaart, G., Kox, M., Dingjan, I., Neerincx, A.H., Bendix, M.B., ter Beest, M., Harren, F.J.M., Risby, T., Pickkers, P., Marczin, N., \& Cristescu, S.M. (2017). Ethylene, an early marker of systemic inflammation in humans. Scientific Reports, 7, article number 6889.

Palzer, S. (2020). Photoacoustic-Based Gas Sensing: A Review. Sensors, 20(9), 2745.

Patimisco, P., Scamarcio, G., Tittel, F.K., \& Spagnolo, V. (2014). Quartz-Enhanced Photoacoustic Spectroscopy: A Review. Sensors, 14(4), 6165-6206. 
Popa, C., Bratu, A.M., \& Petrus, M. (2018). A comparative photoacoustic study of multi gases from human respiration: mouth breathing vs. nasal breathing. Microchemical Journal, 139 196-202.

Popa, C., Petrus, M., \& Bratu, A.M. (2015). Ammonia and ethylene biomarkers in the respiration of the people with schizophrenia using photoacoustic spectroscopy. Journal of Biomedical Optics, 20 (5), 057006.

Ramachandran, S., Prasad, N.R., \& Karthikeyan, S. (2010). Sesamol inhibits UVB-induced ROS generation and subsequent oxidative damage in cultured human skin dermal fibroblasts, Arch Dermatol Res, 302, 733-744.

Timmerman, B.H., Berkelmans, R., Cristescu, S., te Lintel Hekkert, S., de Gruijl, F., Meijers, M., Harren, F.J.M. \& Gerritsen, R. (1999). In-vivo studies of UV effects in human skin using photoacoustics, European UV sunfilters Conference Proc, 19-25.

Wang, Z., Geng, J., \& Ren, W. (2017). Quartz-Enhanced Photoacoustic Spectroscopy (QEPAS) Detection of the 17 Band of Ethylene at Low Pressure with $\mathrm{CO}_{2}$ Interference Analysis. Applied Spectroscopy, 71(8), 1834-1841.

Wang, Z., Li, Z., \& Ren, W. (2016). Quartz-enhanced photoacoustic detection of ethylene using a $10.5 \mu \mathrm{m}$ quantum cascade laser. Optic Express 24 (4). 4143-4154. 